\section{Developing a Vegetable Fertility Program Using Organic Amendments and Inorganic Fertilizers}

\author{
Monica Ozores-Hampton ${ }^{1}$
}

ADDITIONAL INDEX WORDS. cover crops, compost, raw animal manure, nitrogen mineralization, nutrient management, best management practices, BMP

SUMMARY. This review integrates information from common organic amendments used in conventional vegetable production, including 1 ) cover crops (legumes and nonlegumes), 2) compost generated from yard wastes, biosolids, municipal solid waste (MSW), animal manures, and other biodegradable waste by-products, and 3 ) raw animal manure (with and without bedding). Environmental monitoring has shown elevated nitrate concentration to be widespread in both surface and groundwater, often occurring in regions with concentrated horticultural production. Therefore, the objective of this review was to calculate the nutrient content from organic amendments, since these are not considered nutrient sources. Common organic amendments affect soil bulk density, water-holding capacity, soil structure, soil carbon content, macro- and micronutrients, $\mathrm{pH}$, soluble salts, cation exchange capacity (CEC), and biological properties (microbial biomass). The first step in building a conventional tomato (Solanum lycopersicum) fertility program will be to take a soil sample and send it to a soil laboratory for a nutrient analysis. These results should be compared with the local crop recommendations. Second, select the organic amendments based on local cover crop suitability and availability of compost, raw animal manure, or both. Then, determine the nutrients available from cover crops and other applied organic amendments and use inorganic fertilizer sources to satisfy the crop nutrient requirements not supplied from these other sources.

$\mathrm{V}$ egetable production systems in the United States include plasticulture and open bed. These production systems have been effective for commercial production with resulting economic return. Plasticulture generally includes raised beds, fumigation, polyethylene mulch, irrigation, and soluble fertilizer application; open bed production includes herbicides, irrigation, and soluble fertilizer application. However, conventional vegetable growers rarely add organic amendments because the use of concentrated, relatively inexpensive (compared with the value of the crop), and readily available synthetic fertilizers results in high yields with maximum short-term profits (Kelly, 1990). The most common organic amendments that conventional vegetables growers can use are cover crops, compost, and raw manures (Ozores-Hampton et al., 2012).

Incorporating cover crops into vegetable production may enhance

Southwest Florida Research and Education Center, University of Florida, Immokalee, FL 34142

This paper was part of the workshop "Nutrient and Water Management Practices for Improving Crop Growth, Yield, and Quality" held 26 Sept. 2011 at the ASHS Conference, Waikoloa, HI, and sponsored by the Plant Nutrient Management (PNM) Working Group.

${ }^{1}$ Corresponding author. E-mail: ozores@ufl.edu. the sustainability of the system by recycling unused nutrients from previous vegetable crops, improve soil structure, increase soil organic matter $(\mathrm{SOM})$ and fertility, retain moisture, prevent leaching of nutrients, decrease soil density, suppress weeds, increase population of beneficial insects, control erosion, manage plant-parasitic nematodes, increase soil biological activity, and increase yields (Abdul-Baki et al., 1997a, 1997b; McSorley, 1998; Sainju and Singh, 1997; Stivers-Young, 1998; Sullivan, 2003; Treadwell et al., 2008a). Some benefits may occur during the cover crop life cycle, while other benefits may take effect after the cover crop is incorporated (Treadwell et al., 2008b). Disadvantages of growing cover crops within a vegetable production system include additional production cost, delayed vegetable planting, increased pest pressure, immobilization of fertilizer nitrogen (N), and difficult to control ratoon vegetable crop (Treadwell et al., 2008c).
Compost can be defined as "the product of a managed process through which microorganisms break down plant and animal materials into more available forms suitable for application to the soil" (Florida Department of Environmental Protection, 1989). The technological and scientific advances in compost production (DeBertodi et al., 1987; Epstein, 1997), utilization (Stoffella and Kahn, 2001), microbiology (Insam, et al., 2010), and engineering (Haug, 1993), which has occurred during the past two decades, and implications that compost is environmental "friendly" and sustainable have been the reasons for the tremendous increase in worldwide compost usage. In areas of high population, there are a variety of nonhazardous wastes suitable for composting and land application that can provide an economically sound and environmentally acceptable option for utilization, but the majority of these wastes are currently landfilled or burned (Ozores-Hampton et al., 1998). Organic amendments composed of wastes produced by urban populations include MSW; yard trimming; food wastes from restaurants, grocery stores, and institutions; wood wastes from construction, demolition, or both; wastewater (from water treatment plants); and biosolids (sewage sludge). Agriculture produces other organic wastes that can be composted: poultry, dairy, horse, feedlot, and swine manures; wastes from foodprocessing plants; spoiled feeds; and harvest wastes (Ozores-Hampton et al., 1998, 2005; Ozores-Hampton, 2006). The use of organic amendments may improve soil quality and enhance the utilization of fertilizer, thus improving the performance of vegetable crops (Ozores-Hampton et al., 1998, 2011; Ozores-Hampton and Peach, 2002). In addition, compost application may control weeds (Ozores-Hampton et al., 2001a, 2001b), suppress plant diseases (Hoitink and Fachy, 1986; Hoitink et al., 2001), increase SOM, decrease erosion by water and wind (Tyler, 2001), and reduce nutrient leaching (Jaber et al., 2005; Yang et al., 2007).

\begin{tabular}{llll}
\hline $\begin{array}{l}\text { Units } \\
\text { To convert U.S. to SI, } \\
\text { multiply by }\end{array}$ & U.S. unit & SI unit & $\begin{array}{l}\text { To convert SI to U.S., } \\
\text { multiply by }\end{array}$ \\
\hline 0.4536 & $\mathrm{lb}$ & $\mathrm{kg}$ & 2.2046 \\
1.1209 & $\mathrm{lb} / \mathrm{acre}$ & $\mathrm{kg} \cdot \mathrm{ha}^{-1}$ & 0.8922 \\
$\left({ }^{\circ} \mathrm{F}-32\right) \div 1.8$ & ${ }^{\circ} \mathrm{F}$ & ${ }^{\circ} \mathrm{C}$ & $\left({ }^{\circ} \mathrm{C} \times 1.8\right)+32$
\end{tabular}


Increased SOM improves physical properties by decreasing bulk density and increasing available water-holding capacity; chemical properties by increasing $\mathrm{CEC}, \mathrm{pH}$, and macro- and micronutrient supplies (OzoresHampton et al., 2011; Sikora and Szmidt, 2001); and biological properties by increasing soil microbial activity (Ozores-Hampton et al., 2011).

Raw manures supply macro- and micronutrients, and SOM. Increasing SOM improves soil structure or tilth, increases the water-holding capacity, improves drainage, provides a source of slow-release nutrients, reduces wind and water erosion, and promotes growth of earthworms and other beneficial soil organisms (Rosen and Bierman, 2005). However, in areas of intense animal production, overfertilization with animal manure often occurs (Paik et al., 1996). The result is often manifested by nutrients entering adjacent water bodies. To obtain maximum economic value of plant nutrients in animal manure and to protect water supplies from excessive nutrient runoff or leaching, animal manure should be applied to match the most environmentally limiting nutrient needs of a crop. In some states, application of higher manure rates than the most limiting environmentally sensitive nutrient that are required by the vegetable crop $[\mathrm{N}$ or phosphorous $(\mathrm{P})]$ is illegal. The remaining nutrient amount, if any, must be supplied through the use of synthetic fertilizers.

\section{Developing the nutrient budget in conventional vegetable production}

Those using cover crops, composts, and raw animal manures must practice sound soil fertility management to prevent nutrient imbalances and associated health risks, as well as surface water and groundwater contamination. Matching amendment-supplied nutrients to vegetable nutrient requirements should the goal of a conventional vegetable fertility program (OzoresHampton et al., 2011). Overfertilization will be inefficient and expensive, which may contribute to nutrient runoff, groundwater pollution, soil toxicity, pest and disease susceptibility, excessive production of foliage, and reduced vegetable quality and yields. Similarly, underfertilization can reduce vegetable yield, quality, or both. Table 1 provides an analysis of cover crop, compost, and raw animal
Table l. Nitrogen $(\mathrm{N})$, phosphorus $(\mathrm{P})$, and potassium $(\mathrm{K})$ concentrations, and $\mathrm{N}$ mineralization rates of cover crops, compost, and raw animal manures for conventional vegetable crop production.

\begin{tabular}{|c|c|c|c|c|}
\hline \multirow[b]{2}{*}{ Organic material $^{\mathrm{z}}$} & $\mathbf{N}$ & $\mathbf{P}^{\mathrm{y}}$ & $\mathbf{K}^{\mathbf{y}}$ & $\begin{array}{l}\text { Annual rate } \\
\text { of } \mathrm{N} \text { release }\end{array}$ \\
\hline & \multicolumn{4}{|c|}{$(\%)$} \\
\hline \multicolumn{5}{|l|}{ Legume cover crops $^{\mathrm{x}}$} \\
\hline Buckwheat & 1.25 & $0.2-0.4$ & $2.0-4.0$ & $30-50$ \\
\hline Cowpea & $1.4-4.0$ & 0.4 & 1.4 & $30-50$ \\
\hline Crimson clover & 2.7 & 0.4 & 3.4 & $30-50$ \\
\hline Crimsom clover & 3.5 & 0.4 & 3.4 & $30-50$ \\
\hline Hairy vetch & 4.3 & 0.6 & 4.1 & $30-50$ \\
\hline Rye & 1.6 & 0.3 & 1.9 & $30-50$ \\
\hline Sesbania & 4.3 & 0.6 & 3.5 & $30-50$ \\
\hline Soybean & $2.3-7.5$ & 0.7 & 2.4 & $30-50$ \\
\hline Sunnhemp & $1.7-2.3$ & 0.5 & 3.2 & $30-50$ \\
\hline Sweetclover & $2.0-3.0$ & 0.5 & 3.2 & $30-50$ \\
\hline \multicolumn{5}{|l|}{ Nonlegume cover crops $^{x}$} \\
\hline Millet & 1.0 & $0.2-0.4$ & $2.0-4.0$ & $30-50$ \\
\hline Sorghum-sudangrass & 1.5 & $0.2-0.4$ & $2.0-4.0$ & $30-50$ \\
\hline \multicolumn{5}{|l|}{ Compost } \\
\hline Biosolids & $3-6$ & $2-3$ & $0.10-0.15$ & $3.0-20$ \\
\hline Brewery waste solids & $1.3-1.8$ & 0.02 & $0.13-0.18$ & $5.0-10$ \\
\hline Dairy manure & $1.2-1.5$ & 0.3 & 0.9 & $6.0-15$ \\
\hline Feedlot manure & $1.9-2.2$ & $0.3-1.2$ & $0.6-3.2$ & $3.0-15$ \\
\hline Fruit and vegetable wastes & 1.39 & 0.26 & 1.19 & 10 \\
\hline Gin trash & $1.2-3.8$ & 0.2 & 1.2 & 10 \\
\hline Horse manure & 0.5 & 0.2 & 0.4 & 10 \\
\hline Food waste & $1.1-1.8$ & $0.03-0.09$ & $0.35-0.45$ & $2.0-12$ \\
\hline Municipal solid waste & 2.3 & 1.11 & 0.64 & $3.0-10$ \\
\hline Mushrooms & 2.5 & 1.3 & 0.9 & 10 \\
\hline Olive mill waste & 3.5 & 0.17 & 2.3 & 20 \\
\hline Poultry manure & $1.3-5$ & 3.0 & 2.0 & 20 \\
\hline Yard waste & $1.0-1.2$ & $0.2-0.3$ & $0.2-1.4$ & $2.0-10$ \\
\hline \multicolumn{5}{|l|}{ Animal manure } \\
\hline Beef (no bedding) & $0.6-0.7$ & $0.35-0.45$ & $0.5-0.65$ & 35 \\
\hline Beef (with bedding) & & & & 25 \\
\hline Dairy (no bedding) & 0.5 & $0.15-0.3$ & $0.3-0.45$ & 35 \\
\hline Dairy (with bedding) & 0.45 & 0.2 & 0.6 & 25 \\
\hline Goat fresh & 1.1 & 0.6 & 0.9 & 25 \\
\hline Horse (fresh) & 0.6 & 0.3 & 0.6 & 20 \\
\hline Mature compost & $0.8-1.5$ & $0.3-0.5$ & 1.5 & 10 \\
\hline Poultry litter pellets & 4.0 & 2.0 & 2.0 & 21 \\
\hline Poultry broiler house litter & 3.6 & 3.9 & 2.3 & 45 \\
\hline Poultry layer-deep pit & 1.9 & 2.8 & 1.5 & 45 \\
\hline Poultry layer-under cage & 1.3 & 1.6 & 1 & 50 \\
\hline Poultry stock piled litter & 1.8 & 4 & 1.7 & 45 \\
\hline Rabbit (fresh) & 1.2 & 1.2 & 0.7 & 20 \\
\hline Sheep (fresh) & 1.1 & 0.5 & 1.0 & 25 \\
\hline Sheep with bedding & 0.9 & 0.4 & 1.0 & 20 \\
\hline Swine (fresh) & 0.6 & 0.5 & $0.3-0.5$ & 50 \\
\hline Swine (with bedding) & 0.6 & 0.3 & 0.5 & 25 \\
\hline
\end{tabular}

${ }^{\mathrm{z}}$ Altieri and Esposito, 2010; Ahmad et al., 2008; Aram and Rangarajan, 2005; Bellows, 2003; Chellemi and Lazarovits, 2002; Creamer, et al., 1997; Diver, et al., 1999; Drinkwater, 2007; Gaskell, 2009; Gaskell and Smith 2006, 2007; Gaskell and Klauer, 2004; Greer and Adam, 2005; Hartz and Johnstone, 2006; Hartz et al., 2000; Kuepper and Everett 2004; Marr et al., 1998; Prasad, 2009a, 2009b; Pressman, 2009; Sooby et al., 2007; Sullivan, 2003; Rosen and Bierman, 2005; VanTine and Verlinden, 2003; University of California, 2009; Zhang and Li, 2003

${ }^{\mathrm{y}} \mathrm{P} \times 2.2910=\mathrm{P}_{2} \mathrm{O}_{5}, \mathrm{~K} \times 1.2047=\mathrm{K}_{2} \mathrm{O}$

${ }^{x}$ Buckwheat (Fagopyrum esculentum), cowpea (Vigna unguiculata), crimson clover (Trifolium incarnatum), hairy vetch (Vicia villosa), rye (Secale cereale), sesbania (Sesbania exaltata), soybean (Glycine max), sun hemp (Crotalaria juncea), sweetclover (Melilotus officinalis), millet (Pennisetum glaucum), sorghum-sudangrass (Sorghum bicolor $\times$ S. sudanense). 
manure suitable for vegetable production. Since actual nutrient content varies considerably between organic amendment sources, a representative product sample should be sent to a laboratory for analysis of moisture and nutrient content such as total $\mathrm{N}$, phosphate $\left(\mathrm{P}_{2} \mathrm{O}_{5}\right)$, potash $\left(\mathrm{K}_{2} \mathrm{O}\right)$, calcium $(\mathrm{Ca})$, magnesium $(\mathrm{Mg})$, and micronutrients analysis. Additionally, for compost and animal manure nitrate $\left(\mathrm{NO}_{3}\right)$ and ammonium $\left(\mathrm{NH}_{4}\right)$, $\mathrm{N}$ is recommended. Accurate manure or compost analysis requires that a representative sample be submitted; so several subsamples should be collected and combined for analysis. It is important to know the mineralization (decomposition or microbial breakdown) rate of the organic amendment before determining its application rate to vegetables. The rate of $\mathrm{N}$ release or availability is especially important because this nutrient moves readily through sandy soils. Evaluations of $\mathrm{N}$ mineralization in situ can be used to improve $\mathrm{N}$ use efficiency. However, the direct, quantitative measurement of $\mathrm{N}$ mineralization in situ is difficult because of the complex and dynamic nature of $\mathrm{N}$ transformations in the soil environment (Preusch et al., 2002).

Cover Crops. There are legume and nonlegume cover crops that can be used in a conventional vegetable production system (Table 2). Biomass, N content, or both can be increased by a cover crop mixture. Cover crops provide organic $\mathrm{N}$, which benefits succeeding vegetable crops, for example, 1.0 and $2.0 \mathrm{lb}$ per $100 \mathrm{lb}$ of dry weight for grasses and legumes, respectively (Treadwell et al., 2008b). However, the availability of $\mathrm{N}$ from the cover crops may not coincide with the $\mathrm{N}$ uptake requirements of the vegetable crop. Thus, vegetable yield and quality may be adversely affected by short-term shortages or a short lag time between the release of the $\mathrm{N}$ from the cover crop and subsequent vegetable crop uptake can result in $\mathrm{NO}_{3}-\mathrm{N}$ pollution by leaching (Weinert et al., 2002).

Compost AND Composting. There are no U.S. government restrictions on how and when compost can be used in vegetable production, except compost derived from sewage sludge or biosolids [Ozores-Hampton and Peach, 2002; U.S. Environmental Protection Agency (USEPA), 1994, 1995, 1999]. To eliminate or reduce human and plant pathogen, nematodes, and weeds, the temperature during the compost process must remain between 131 and $170{ }^{\circ} \mathrm{F}$ for $3 \mathrm{~d}$ in an in-vessel or static aerated pile or $15 \mathrm{~d}$ in windrows, which must be turned at least five times during this period (USEPA, 1994, 1995, 1999). More than $90 \%$ of the total $\mathrm{N}$ in compost will be in an organic form and only $10 \%$ will be in the inorganic forms of $\mathrm{NO}_{3}-\mathrm{N}$ or $\mathrm{NH}_{4}-\mathrm{N}$ (Hartz et al., 2000). Therefore, application time may not be as critical as compared with raw animal manures. The composting process converted raw organic materials such as raw manure high in $\mathrm{NH}_{4}$ and $\mathrm{NO}_{3}$, which is susceptible to runoff or leaching, to a humus-stable form minimizing the environmental impact on air and groundwater contamination. Compost $\mathrm{N}$ mineralization rates or $\mathrm{N}$ availability will vary depending on compost feedstocks, soil characteristics, and environmental conditions. It is generally considered that $\mathrm{N}$ immobilization occurs in composts when the initial carbon to nitrogen $(\mathrm{C}: \mathrm{N})$ ratio is greater than 20:1 and mineralization occurs when $\mathrm{C}: \mathrm{N}$ ratio is lower than 20:1. However, $\mathrm{C}: \mathrm{N}$ ratio as a predictor of $\mathrm{N}$ mineralization is not exact, as it may depend on the type of C (Prasad, 2009a; Rosen and Bierman, 2005; Wallace, 2006). Mineralization $\mathrm{N}$ rates guidelines developed by Wallace (2006) indicated that the availability of $\mathrm{N}$ will be $0 \%$ to $20 \%$ or even negative in the first year and $0 \%$ to $8 \%$ in the following years. However, $\mathrm{P}$ and potassium (K) will not react as $\mathrm{N}$ when compost will be added to soil. $\mathrm{P}$ and $\mathrm{K}$ in compost will be readily available to plants as commercial fertilizer. This is because the OM content in the compost will block sites where $\mathrm{P}$ will be adsorbed; in addition the compost biological activity can cause the release of soil-bound $\mathrm{P}$ resulting in a net $\mathrm{P}$ up-take by the crop. There were no differences between compost and commercial $\mathrm{P}$ in studies using biosolids compost or manure compost (Preusch et al., 2002; Sikora and Enkiri, 2003). Hence, a compost end user should be cautious when using compost as an $\mathrm{N}$ fertilizer because only a portion of the $\mathrm{N}(5 \%$ to $30 \%)$ will behave as a commercial fertilizer during the first year, but all the $\mathrm{P}$ and $\mathrm{K}$ in the compost will react as a commercial fertilizer. Therefore, compost application on sensitive land to $\mathrm{P}$ addition should be done based on crop $\mathrm{P}$ rather than $\mathrm{N}$ crop requirements (Preusch et al., 2002; Sikora and Enkiri, 2003).

RaW animal manures. Manures are an excellent source of nutrients and can be incorporated into most fertility programs. The nutrient content in manures varies with animal type, bedding, storage, and processing. Nutrient analysis of manure may be required by law in some cases, but analysis is always recommended and should include total $\mathrm{N}, \mathrm{NH}_{4}-\mathrm{N}, \mathrm{P}_{2} \mathrm{O}_{5}$, and $\mathrm{K}_{2} \mathrm{O}$. Usually $25 \%$ to $50 \%$ of the organic-N in fresh manure will be available during the first year (Table 1; Rosen and Bierman, $2005)$. If the manure contains bedding or is composted, the percentage of organic $\mathrm{N}$ will be lower. Raw animal manure contains more $\mathrm{NH}_{4}-\mathrm{N}$ content than compost, which increases the risk of volatilization to ammonia $\left(\mathrm{NH}_{3}\right)$ gas. Therefore, raw animal manure should be field incorporated within $12 \mathrm{~h}$ of application to decrease $\mathrm{NH}_{3}-\mathrm{N}$ losses (Rosen and Bierman, 2005).

Proposed P availability from various compost made from different feedstock relative to superphosphate are available for spent mushroom compost (100\%), animal manures (90\%), sewage sludge $(85 \%)$, source-separated food waste $(75 \%)$, and yard waste $(60 \%)$ (Prasad, 2009b). However, generally for compost or raw animal manures, $70 \%$ to $80 \%$ of the $\mathrm{P}$ and $80 \%$ to $90 \%$ of the $\mathrm{K}$ will be available from manure during the first year after application (Rosen and Bierman, 2005). To calculate the correct application rate of compost or raw animal manure, multiply by availability factors (70\% to $80 \%$ for $\mathrm{P}$ and $80 \%$ to $90 \%$ for $\mathrm{K}$ ) to obtain the amount of $\mathrm{P}$ and $\mathrm{K}$ that will be available to vegetables from the application of composted or raw animal manure. Then, multiply the total P by 2.2910 and $\mathrm{K}$ by 1.2047 to obtain $\mathrm{P}_{2} \mathrm{O}_{5}$ and $\mathrm{K}_{2} \mathrm{O}$ (Table $\mathrm{l}$ ). The advantage using compost rather than raw manure will be that, although $\mathrm{P}$ can be overapplied with compost, the improvement in soil structure with the compost OM application will increase water infiltration and reduce runoff, thereby decreasing the total P transported over the land surface to potentially pollute surface water (Spargo et al., 2006).

For successful integration of organic amendments into conventional vegetable fertility programs, we recommended the construction of an $\mathrm{N}-\mathrm{P}-\mathrm{K}$ crop mass balance where the fertility inputs and net release of $\mathrm{N}$ will be quantified, and vegetable crop $\mathrm{N}-\mathrm{P}_{2} \mathrm{O}_{5}$ $\mathrm{K}_{2} \mathrm{O}$ requirement will be taken into consideration (Table 3). Calculating 
Table 2. Cover crop biomass dry weight production, location, total nitrogen $(\mathrm{N})$ contributions, and source.

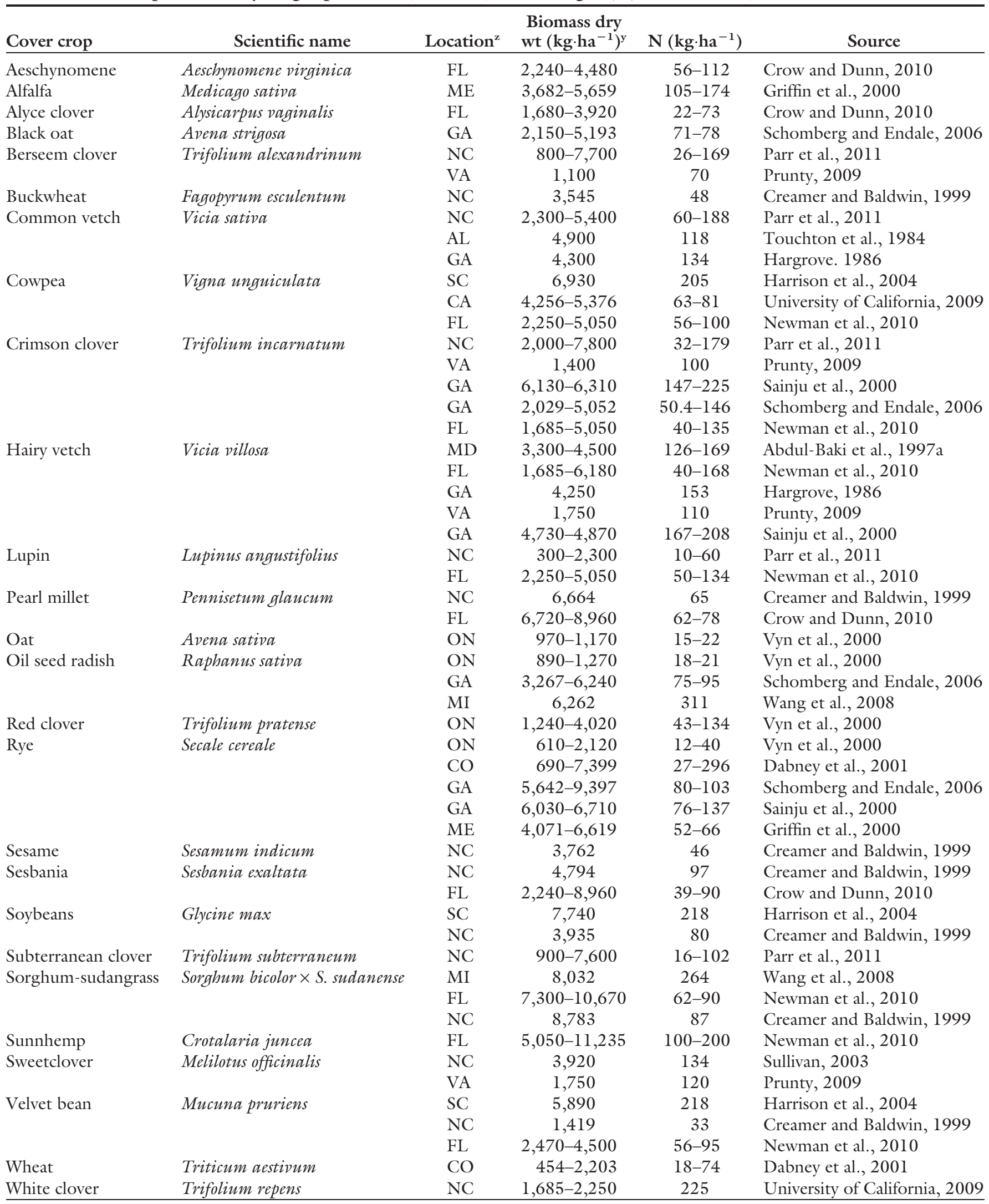

${ }^{2}$ U.S. Postal Service abbreviations for U.S. states and Canadian provinces. ${ }^{\mathrm{y}} \mathrm{l} \mathrm{kg} \cdot \mathrm{ha}^{-1}=0.8922 \mathrm{lb} /$ acre. 
Table 3. Florida nutrient mass budget for conventional tomato production. Tomato nutrient requirements based on $224 \mathrm{~kg} \cdot \mathrm{ha}^{-1}$ (i.e., $200 \mathrm{lb} /$ acre) of nitrogen (N), $112 \mathrm{~kg} \cdot \mathrm{ha}^{-1}$ (i.e., $100 \mathrm{lb} /$ acre) phosphoric acid $\left(\mathrm{P}_{2} \mathrm{O}_{5}\right)$, and $112 \mathrm{~kg} \cdot \mathrm{ha}^{-1}$ potassium oxide $\left(\mathrm{K}_{2} \mathrm{O}\right)$ with medium soil test levels of phosphorus $(\mathrm{P})$ and potassium (K), respectively (Olson et al., 2010$)$.

\begin{tabular}{|c|c|c|c|c|c|c|}
\hline Material inputs ${ }^{\mathrm{z}}$ & $\begin{array}{l}\text { Application rate } \\
\left(\mathrm{kg} \cdot \mathrm{ha}^{-1} \text { dry }^{\mathrm{t} t}\right)^{\mathrm{z}}\end{array}$ & $\begin{array}{c}\text { N rate } \\
\left(\mathrm{kg} \cdot \mathrm{ha}^{-1}\right)\end{array}$ & $\begin{array}{l}\mathrm{N} \text { mineralization } \\
\text { rate }(\%)\end{array}$ & $\begin{array}{l}\text { Total } \mathrm{NO}_{3} \\
\left(\mathrm{~kg} \cdot \mathrm{ha}^{-1}\right)^{\mathrm{y}}\end{array}$ & $\begin{array}{l}\text { Total } \mathrm{P}_{2} \mathrm{O}_{5} \\
\left(\mathrm{~kg} \cdot \mathrm{ha}^{-1}\right)^{\mathrm{x}}\end{array}$ & $\begin{array}{l}\text { Total } \mathrm{K}_{2} \mathrm{O} \\
\left(\mathrm{kg} \cdot \mathrm{ha}^{-1}\right)^{\mathrm{x}}\end{array}$ \\
\hline \multicolumn{7}{|l|}{ Soil and organic amendments application } \\
\hline $\begin{array}{l}\text { Sorghum-sudangrass with } \\
1.5 \% \mathrm{~N}, 0.2 \% \mathrm{P} \text {, and } 2 \% \mathrm{~K} \\
\text { with } 70 \% \mathrm{P} \text { and } 80 \% \mathrm{~K} \text { availability }\end{array}$ & 8,783 & 131.7 & 23 & 30.3 & 28.2 & 168.7 \\
\hline $\begin{array}{l}\text { Yard waste compost at } 10 \mathrm{Mg} \cdot \mathrm{ha}^{-1} \\
(40 \% \text { moisture and } 1 \% \mathrm{~N}, 0.2 \% \mathrm{P} \text {, } \\
\text { and } 0.8 \% \mathrm{~K} \text { with } 70 \% \mathrm{P} \\
\text { and } 80 \% \mathrm{~K} \text { availability }\end{array}$ & 6000 & 60.0 & 10 & 6.0 & 19.2 & 38.4 \\
\hline Subtotal & 14783 & 191.7 & - & 36.3 & 47.4 & 207.1 \\
\hline \multicolumn{7}{|l|}{ Inorganic fertilizer application $^{\mathrm{w}}$} \\
\hline Ammonium nitrate & 552.1 & & & 187.7 & - & - \\
\hline Triple phosphate & 140.4 & & & - & 64.6 & - \\
\hline Total & 一 & - & & 224 & 112 & 112 \\
\hline
\end{tabular}

${ }^{\mathrm{z}} \mathrm{l} \mathrm{Mg} \cdot \mathrm{ha}^{-1}=0.4461 \mathrm{ton} / \mathrm{acre}, \mathrm{l} \mathrm{kg} \cdot \mathrm{ha}^{-1}=0.8922 \mathrm{lb} / \mathrm{acre}$.

$\mathrm{NO}_{3}=$ nitrate.

${ }^{x} \mathrm{P}_{2} \mathrm{O}_{5} \times 0.4365=\mathrm{P}, \mathrm{K}_{2} \mathrm{O} \times 0.8301=\mathrm{K}$.

"Ammonium nitrate $(34 \% \mathrm{~N})$, triple phosphate $\left(46 \% \mathrm{P}_{2} \mathrm{O}_{5}\right)$.

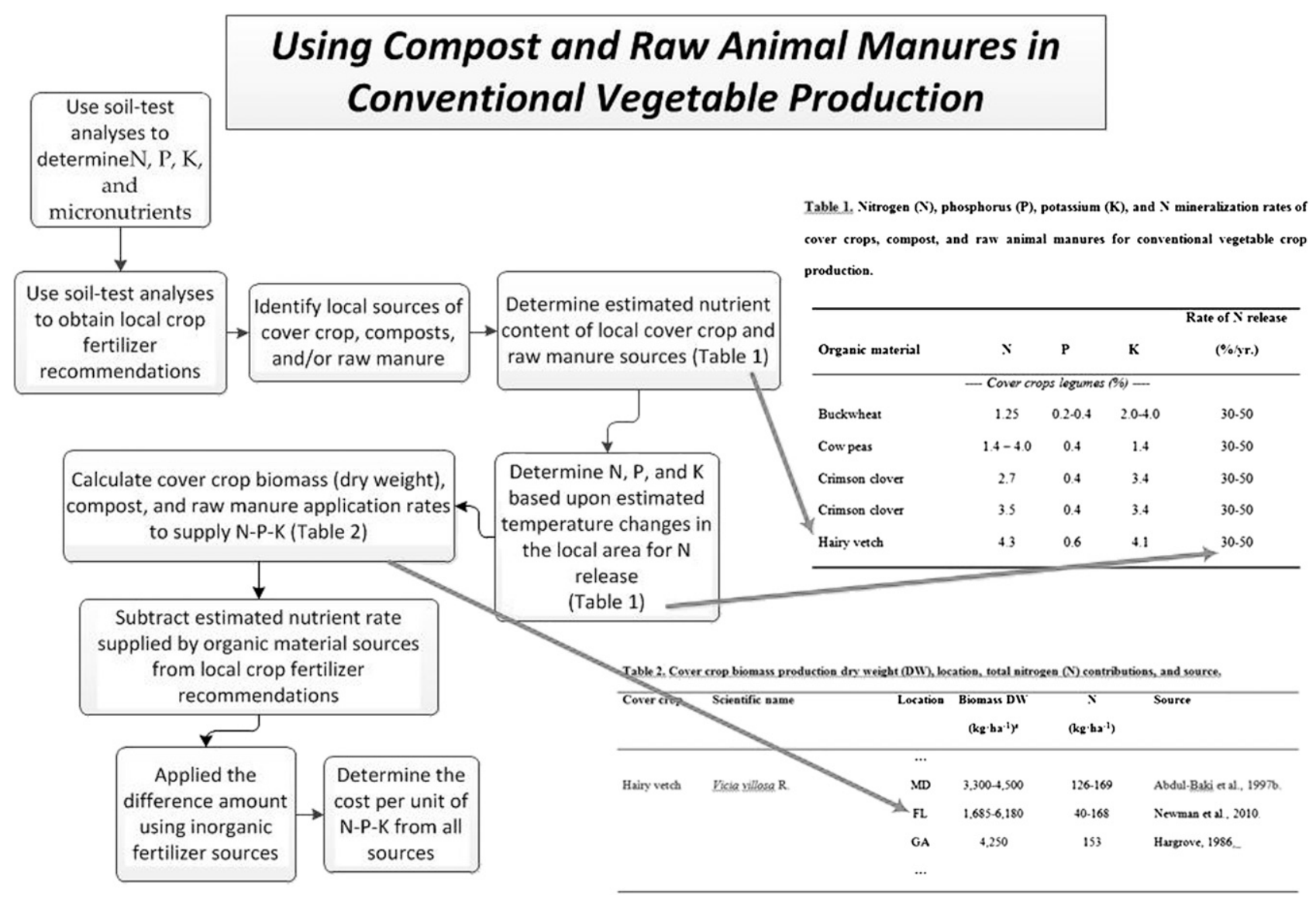

Fig. 1. Diagram of process for calculating the contribution of nutrients from selected organic sources to satisfy the crop nutrient requirements for commercial vegetable production using the tables in this document.

$\mathrm{N}$ availability from organic amendments can be complex as $\mathrm{N}$ must be transformed by soil microorganisms before it can be used by the vegetable crop as $\mathrm{NO}_{3}-\mathrm{N}$. An example of a tomato fertility program for Florida is provided as a guide (Table 3). A flowchart (Fig. 1) shows the calculations diagrammatically. The first step in building the tomato fertility program is to determine the nutrient requirements of tomato crop by taking a soil sample for analysis of $\mathrm{N}-$ $\mathrm{P}-\mathrm{K}$ and micronutrients. These results can be compared with the local crop recommendations for $\mathrm{N}-\mathrm{P}_{2} \mathrm{O}_{5}-\mathrm{K}_{2} \mathrm{O}$. 
This information can be found in a local state or regional "vegetable production handbook," or contact a local extension faculty. Then, the identification of cover crops suitable for the location and locally available compost and raw animal manures can be obtained from the local state or regional "vegetable production handbook," or contact a local extension faculty. Once cover crop, compost, and raw animal manure are located and identified, determine the nutrient content and $\mathrm{N}, \mathrm{P}$, and $\mathrm{K}$ availability from laboratory analysis or other sources as shown in Table 2 . The microbial activity involved in the $\mathrm{N}$ cycles, which is accelerated by high temperatures and slowed down with low temperatures needs to be considered and $\mathrm{N}$ release rate adjusted as needed. The next step will be the calculation of the cover crop biomass production (dry weight), and compost and raw animal manure application rates to supply recommended amounts of $\mathrm{N}, \mathrm{P}_{2} \mathrm{O}_{5}$, and $\mathrm{K}_{2} \mathrm{O}$ to the tomato crop so that yield estimates are realized (Tables 1 and 2). Finally, determine whether application of inorganic commercial fertilizer is needed. Once a fertility program is established, a unit cost per nutrient can be calculated. The cost per unit of nutrients can be calculated by multiplying the unit cost of the nutrient fertilizer with the available nutrient content of the organic amendment and then select the most costeffective one to be applied to the tomato crop.

The fertility program for conventional vegetable production can be divided into two major parts: an organic-amendment-based program consisting of cover crops, compost, or raw animal manures and a supplemental fertility program consisting of inorganic fertilizer application such as ammonium nitrate, urea, potassium sulfate, etc. plus micronutrients to supply the plant nutrient requirements.

\section{Literature cited}

Abdul-Baki, A.A., R.D. Morse, T.E. Devine, and J.R. Teasdale. 1997a. Broccoli production in forage soybean and foxtail millet cover crop mulches. HortScience 32:836-839.

Abdul-Baki, A.A., J.R. Teasdale, and R. Korcak. 1997b. Nitrogen requirement of fresh-market tomatoes on hairy vetch and black polyethylene mulch. HortScience 32:217-221
Ahmad, R., M. Naveed, M. Aslam, Z.A. Zahir, M. Arshad, and G. Jilani. 2008. Economizing the use of nitrogen fertilizer in wheat production through enriched compost. Renewable Agr. Food Systems 23:243-249.

Altieri, R. and A. Esposito. 2010. Evaluation of the fertilizing effect of olive mill waste compost in short-term crops. Intl. Biodeterior. Biodegradation 64:124128.

Aram, K. and A. Rangarajan. 2005. Compost for nitrogen fertility management of bell pepper in a drip-irrigated plasticulture system. HortScience 40:577-581.

Bellows, B. 2003. Protecting water quality on organic farms, p. 1-36. In: J. Ridle and J. Ford (eds.). Organic crops workbook: A guide to sustainable and allowed practices. Natl. Ctr. Appropriate Technol., Fayetteville, AR.

Chellemi, D.O. and G. Lazarovits. 2002. Effect of organic fertilizer applications on growth, yield and pests of vegetables crops. Proc. Florida State Hort. Soc. 115:315-321.

Creamer, N.G. and K.R. Baldwin. 1999. Summer cover crops. North Carolina Coop. Ext. Serv. HIL-37. 3 Mar. 2012. <http://www.ces.ncsu.edu/depts/hort/ hil/hil-37.html>.

Creamer, N.G., M.A. Bennett, and B.R. Stinner. 1997. Evaluation of cover crop mixtures for use in vegetables production systems. HortScience 32:866-870.

Crow, W.T. and R.A. Dunn. 2010. Soil organic matter, green manures and cover crops for nematodes management. Univ. Florida, Inst. Food Agr. Sci. EDIS SSAGR-66. 1 Mar. 2012. <http://edis.ifas. ufl.edu/pdffiles/VH/VH03700.pdf>.

Dabney, S.M., J.A. Delgado, and D.W. Reeves. 2001. Using winter cover crops to improve soil and water quality. Commun. Soil Sci. Plant Anal. 32:1221-1250.

DeBertodi, M., M.P. Ferranti, P. L'Hermite, and F. Zucconi. 1987. Compost: Production, quality and use. Elsevier Appl. Sci., London.

Florida Department of Environmental Protection. 1989. Criteria for the production and use of compost made from solid waste. Florida Administrative Code, Chapter 17-709. Florida Dept. Environ. Protection, Tallahassee, FL.

Diver, S., G. Kuepper, and H. Born. 1999. Organic tomato production. Appropriate technology transfer for rural areas. 3 Mar. 2012. <https://attra.ncat.org/attra-pub/ viewhtml.php?id=33>.

Drinkwater, L. 2007. On-farm budgets in organic cropping systems: A tool for fertility management. I Mar. 2012. <http://ofrf. org/funded/summaries/drinkwater-03slnutrient $\% 20$ budgets.pdf>.

Epstein, E. 1997. The science of composting. CRC Press, Boca Raton, FL.

Gaskell, M. 2009. In-season fertilization in organic systems. 28 July 2011 . <http:// cesantabarbara.ucdavis.edu/files/75469. pdf>.

Gaskell, M. and H. Klauer. 2004. The effect of green manure, compost and feather meal on soil nitrogen dynamics and bell pepper yield. 1 Mar. 2012. $<$ http://ofrf.org/funded/reports/gaskell_ 99-64.pdf $>$.

Gaskell, M. and R. Smith. 2006. Soil fertility management for organic crops. 28 July 2011.<http://ucanr.org/freepubs/ docs/7249.pdf>.

Gaskell, M. and R. Smith. 2007. Nitrogen sources for organic vegetable crops. 11 Jan. 2011. <http://vric.ucdavis.edu/ slectnewtopic.organic.htm $>$.

Greer, L. and K.L. Adam. 2005. Plug and transplant production for organic systems. Appropriate technology transfer for rural areas. 12 Feb. 2011. <http:// attra.ncat.org/attra-pub/PDF/plugs. pdf $>$.

Griffin, T., M. Liebman, and J. Jemison. 2000. Cover crops for sweet corn production in a short-season environment. Agron. J. 92:144-151.

Hargrove, W.L. 1986. Winter legumes as a nitrogen source for no-till grain sorghum. Agron. J. 78:70-74.

Harrison, H.F., D.M. Jackson, P.C. Marino, and T. Pullaro. 2004. Broccoli production in cowpea, soybean, and velvetbean, cover crop mulches. HortTechnology 14:484-487.

Hartz, T.K. and P.R. Johnstone. 2006. Nitrogen availability from high-nitrogencontaining organic fertilizers. HortTechnology 16:39-42.

Hartz, T.K., J.P. Mitchell, and C. Giannini. 2000. Nitrogen and carbon mineralization dynamics of manures and composts. HortScience 35:209-212.

Haug, R.T. 1993. The practical handbook of compost engineering. Lewis Publishers, Boca Raton, FL.

Hoitink, H.A. and P.C. Fachy. 1986. Basis for the control of soil-borne plant pathogens with composts. Annu. Rev. Phytopathol. 24:93-114.

Hoitink, H.A., M.S. Krause, and D.Y. Han. 2001. Spectrum and mechanisms of plant disease control with composts, p. 263-274. In: P.J. Stoffella and B.A. Kahn (eds.). Compost utilization in horticultural 
cropping systems. CRC Press, Boca Raton, FL.

Insam, H., N. Riddech, and S. Klammer, (eds.). 2010. Microbiology of composting. Springer- Verlag, Berlin, Germany.

Jaber, F.H., S. Shukla, P.J. Stoffella, T.A. Obreza, and E.A. Hanlon. 2005. Impact of organic amendments on groundwater nitrogen concentrations for sandy and calcareous soils. Compost Sci. Util. 13:194-202.

Kelly, W.C. 1990. Minimal use of synthetic fertilizers in vegetable production. HortScience 25:168-169.

Kuepper, G. and K. Everett. 2004. Potting mixes for certified organic production. I Mar. 2012. <https://attra.ncat. org/attra-pub/summaries/summary.php? $\mathrm{pub}=47>$

Marr, C.W., R. Janke, and P. Conway. 1998. Cover crops for vegetable growers. Kansas State Univ. Coop. Ext. Serv. MF 2345 .

McSorley, R. 1998. Alternative practices for managing plant-parasitic nematodes. Amer. J. Altern. Agr. 13:98-104.

Newman, Y.C., D.L. Wright, C. Mackowiak, J.M.S. Scholberg, C.M. Cherr, and C.G. Chambliss. 2010. Cover crops. Univ. Florida, Inst. Food Agr. Sci. EDIS SS-AGR-66. I Mar. 2012. <http://edis.ifas.ufl.edu/ aa217>.

Olson, S.M., W.M. Stall, G.E. Vallad, S.E. Webb, S.A. Smith, E.H. Simonne, E. McAvoy, and B.M. Santos. 2010. Tomato production in Florida, p. 295-316 In: S.M. Olson and B. Bielinski (eds.). 2010-2011 Vegetable production handbook for Florida. Vance Publishing, Lenexa, KS.

Ozores-Hampton, M. 2006. Soil and nutrient management: Compost and manure, p. 36-40. In: J.L. Gillett, H.N. Petersen, N.C. Leppla, and D.D. Thomas (eds.). Grower's IPM guide for Florida tomato and pepper production, Univ. Florida, Gainesville.

Ozores-Hampton, M., P. Roberts, and P.A. Stansly. 2012. Organic pepper production, p. 165-175. In: V. Russo (ed.). Peppers: Botany, production and uses. CABI, Wallingford, UK.

Ozores-Hampton, M.P., T.A. Obreza, and G. Hochmuth. 1998. Composted municipal solid waste use on Florida vegetable crops. HortTechnology 8:10-17.

Ozores-Hampton, M., T.A. Obreza, and P.J. Stoffella. 2001a. Weed control in vegetable crops with composted organic mulches, p. 275-286. In: P.J. Stoffella and B.A. Kahn (eds.). Compost utilization in horticultural cropping systems. CRC Press, Boca Raton, FL.
Ozores-Hampton, M.P., T.A. Obreza, P.J. Stoffella, and G. Fitzpatrick. 2001b. Immature compost suppresses weed growth under greenhouse conditions. Compost Sci. Util. 10:105-113.

Ozores-Hampton, M.P. and D.R. Peach. 2002. Biosolids in vegetable production systems. HortTechnology 12:18-22.

Ozores-Hampton, M.P., P.A. Stansly, R. McSorley, and T.A. Obreza. 2005. Effects of long-term organic amendments and soil solarization on pepper and watermelon growth, yield, and soil fertility. HortScience 40:80-84.

Ozores-Hampton, M.P., P.A. Stansly, and T.P. Salame. 2011. Soil chemical, biological and physical properties of a sandy soil subjected to long-term organic amendments. J. Sustain. Agr. 353:243-259.

Paik, I.K., R. Blair, and J. Jacob. 1996. Strategies to reduce environmental pollution from animal manure -principles and nutritional management - A review. Asian-Austral. J. Anim. Sci. 9:615-635.

Parr, M., J.M. Grossman, S.C. RebergHorton, C. Brinton, and C. Crozier. 2011. Nitrogen delivery from legume cover crops in non-till organic corn production. Agron. J. 103:1578-1590.

Pressman, A. 2009. Sources of organic fertilizers \& amendments. 28 July 2011. $<$ https://attra.ncat.org/attra-pub/org_ fert $/>$.

Prasad, M. 2009a. A literature review on the availability of nitrogen from compost in relation to the nitrate regulations SI 378 of 2006. Environ. Protection Agency, Wexford, Ireland.

Prasad, M. 2009b. A literature review on the availability of phosphate from compost in relation to the nitrate regulations SI 378 of 2006. Environ. Protection Agency, Wexford, Ireland.

Preusch, P.L., P.R. Adler, L.J. Sikora, and T.J. Tworkoski. 2002. Nitrogen and phosphorus availability in composted and uncomposted poultry litter. J. Environ. Qual. 31:2051-2057.

Prunty, R. 2009. Building soil organic matter with cover crops. 1 Mar. 2012. <http://pubs.ext.vt.edu/2906/29061381/2906-1381.html>.

Rosen, C.J. and P.M. Bierman. 2005. Using manure and compost as nutrient sources for fruit and vegetable crops. Univ. Minnesota Ext. Serv. M1192. 28 July 2011. <http://www.extension.umn. edu/distribution/horticulture/Ml192. html>.

Sainju, U.M. and B.P. Singh. 1997. Winter cover crops for sustainable agricultural systems: Influence on soil properties, water quality, and crop yields. HortScience 32:21-28.

Sainju, U.M., B.P. Singh, and W.F. Whitehead. 2000. Cover crops and nitrogen fertilization effects on soil carbon and nitrogen and tomato yield. Can. J. Soil Sci. 80:523-532.

Schomberg, H.H. and D.M. Endale. 2006. Influence of cover crops on potential nitrogen availability to succeeding crops in a Southern Piedmont soil. Biol. Fertil. Soils 42:299-307.

Sikora, L.J. and N.K. Enkiri. 2003. Availability of poultry litter compost $\mathrm{P}$ to fescue compared with triple super phosphate. Soil Sci. 168:192-199.

Sikora, L.J. and R.A.K. Szmidt. 2001. Nitrogen sources, mineralization rates, and nitrogen nutrition benefits to plants from composts, p. 287-306. In: P.J. Stoffella and B.A. Kahn (eds.). Compost utilization in horticultural cropping systems. CRC Press, Boca Raton, FL.

Sooby, J., J. Landeck, and M. Lipson. 2007. Soil: Microbial life, fertility management, and soil quality, p. 20-33. In: National organic research agenda. Organic Farming Res. Foundation, Santa Cruz, CA.

Spargo, J.T., G.K. Evanylo, and M.M. Alley. 2006. Repeated compost application effects on phosphorus runoff in the Virginia Piedmont. J. Environ. Qual. 35:23422351

Stivers-Young, L. 1998. Growth, nitrogen accumulation, and weed suppression by fall cover crops following early harvest of vegetables. HortScience 33:60-63.

Stoffella, P.J. and B.A. Kahn (eds.). 2001. Compost utilization in horticultural cropping systems. CRC Press, Boca Raton, FL.

Sullivan, P. 2003. Overview of cover crops and green manures. Appropriate technology transfer for rural areas. 28 July 2011. <https://attra.ncat.org/attrapub/summaries/summary.php?pub=288>.

Touchton, J.T., D.H. Rickerl, R.H. Walker, and C.E. Snipes. 1984. Winter legumes as a nitrogen source for no-tillage cotton. Soil Tillage Res. 4:391-401.

Treadwell, D., M.A. Alligood, C.A. Chase, and M. Bhan. 2008a. Soil nitrogen responses to increasing crop diversity and rotation in organic vegetable production systems. HortScience 43:1107 (abstr.).

Treadwell, D., W. Klassen, and M. Alligood. 2008b. Annual cover crops in Florida vegetable systems, Part 1. Objectives: Why grow cover crops? Univ. Florida, Inst. Food Agr. Sci. EDIS HS387. I Mar. 2012. <http://edis.ifas.ufl.edu/pdffiles/HS / HS38700.pdf>. 
Treadwell, D., W. Klassen, and M. Alligood. 2008c. Annual cover crops in Florida vegetable systems, Part 2. Production. Univ. Florida, Inst. Food Agr. Sci. EDIS HS114. 1 Mar. 2012. <http://edis.ifas.ufl.edu/ pdffiles/HS/HS38900.pdf>.

Tyler, R. 2001. Compost filter berms and blankets take on the silt fence. Biocycle 41-46.

University of California. 2009. UC Sustainable Agriculture Research and Extension Program. 28 July 2011. <http://www.sarep. ucdavis.edu/ccrop/search_ccrop.html>.

U.S. Environmental Protection Agency. 1994. A plain English guide to the EPA part 503 biosolids rule. EPA832-R-93-003. U.S. Environmental Protection Agency, Washington, DC.

U.S. Environmental Protection Agency. 1995. A guide to the biosolids risk assessments for the EPA part 503 rule.
EPA832-B-93-005. U.S. Environmental Protection Agency, Washington, DC.

U.S. Environmental Protection Agency. 1999. Biosolids generation, use, and disposal in the United States. EPA503-R-99-009. U.S. Environmental Protection Agency, Washington, DC.

VanTine, M. and S. Verlinden. 2003. Growing organic vegetable transplants. 28 July 2011. <http://anr.ext.wvu.edu/r/ download/51444>.

Vyn, T.J., J.G. Faber, K.J. Janovicek, and E.G. Beauchamp. 2000. Cover crop effects on nitrogen availability to corn following wheat. Agron. J. 92:915-924.

Wallace, P. 2006. Production of guidelines for using compost in crop production-A brief literature review. Project code ORG 0036, Waste Resources Action Programme. 12 July 2012. <http://www.cre.ie/docs/ Nitrogen\%20Review.pdf>.
Wang, G., M. Ngouajio, and D.D. Warncke. 2008. Nutrient cycling, weed suppression, and onion yield following brassica and sorghum sudangrass cover crops. Hort Technology 18:68-74.

Weinert, T.L., W.L. Pan, M.R. Moneymaker, G.S. Santo, and R.G. Stevens. 2002. Nitrogen recycling by non-leguminous winter cover crops to reduce leaching in potato rotations. Agron. J. 94:365-372.

Yang, J., Z. He, Y. Yang, P.J. Stoffella, X.E. Yang, D.J. Banks, and S. Mishra. 2007. Use of amendments to reduce leaching of phosphate and other nutrients from a sandy soil in Florida. Environ. Sci. Pollution Res. 14:266-269.

Zhang, M. and Y.C. Li. 2003. Nutrient availability in a tomato production systems amended with compost. Acta Hort. 614:787-797. 